\title{
Nitrogen use efficiency and residual effect of fertilizers with nitrification inhibitors
}

\author{
M. Alonso-Ayuso, J.L. Gabriel, M. Quemada* \\ Technical University of Madrid, Dpto. Producción Agraria, Avd. Complutense s/n, 28040 Madrid, Spain
}

\section{A R T I C L E I N F O}

\section{Article history:}

Received 1 February 2016

Received in revised form 11 June 2016

Accepted 16 June 2016

\section{Keywords:}

Ammonium sulfate nitrate

DMPP

Fertilizer use efficiency

Nitrogen recovery

\begin{abstract}
A B S T R A C T
Blending fertilizers with nitrification inhibitors (NI) is a technology to reduce nitrogen (N) losses. The application of NI could increase the soil N supply capacity over time and contribute to an enhancement of N use efficiency (NUE) in some cropping systems. The objectives were to determine in a field experiment located in Central Spain (i) the effect of NI-fertilizers applied to maize (Zea mays L.) during two seasons on yield, $\mathrm{N}$ content and NUE compared to conventional fertilizers, (ii) the soil residual effect of NI-fertilizers in a non-fertilized sunflower (Helianthus annuus L.) planted during a third season, and (iii) the possible sources of residual $\mathrm{N}$ via laboratory determinations. The maize was fertilized with ammonium sulfate nitrate (ASN) and DMPP (3,4-dimethylpyrazole phosphate) blended ASN (ENTEC $\left.{ }^{\circledR}\right)$ at two levels (130 and $170 \mathrm{~kg} \mathrm{~N} \mathrm{ha}^{-1}$ ). A control treatment with no added $\mathrm{N}$ fertilizer was included to calculate NUE. The second year, DMPP application allowed a $23 \%$ reduction of the fertilizer rate without decreasing crop yield or grain quality. In addition, the sunflower planted after the maize scavenged more $\mathrm{N}$ in treatments previously treated with ENTEC ${ }^{\circledR}$ than with traditional fertilizers, increasing NUE in the cropping systems. After DMPP application, $\mathrm{N}$ was conserved in non-ready soil available forms during at least one year and subsequently released to meet the sunflower crop demand. The potential $\mathrm{N}$ mineralization obtained from aerobic incubation under controlled conditions of soil samples collected before sunflower sowing was higher for ENTEC ${ }^{\circledast}$ than ASN or control treatments. A higher $\delta^{15} \mathrm{~N}$ in the soil indicated larger non-exchangeable $\mathrm{NH}_{4}{ }^{+}$fixation in soils from the plots treated with ENTEC ${ }^{\circledR}$ or ASN-170 than from the ASN-130 or the control. These results open the opportunity to increase NUE by designing crop rotations able to profit from the effect of NI on the soil residual N.
\end{abstract}

(c) 2016 Elsevier B.V. All rights reserved.

\section{Introduction}

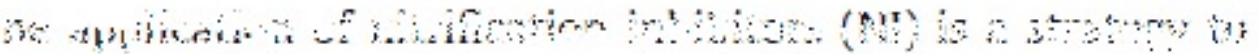

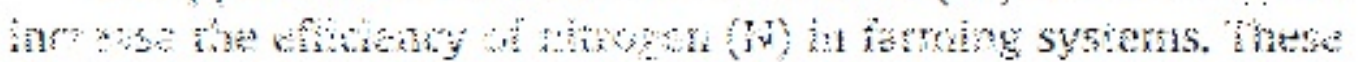

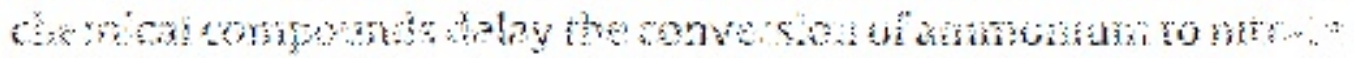

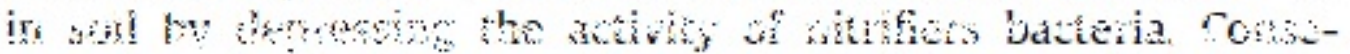

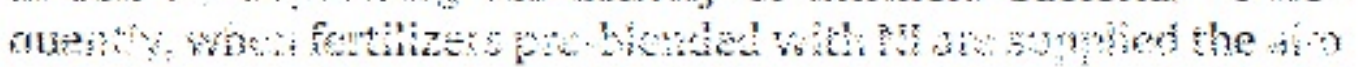

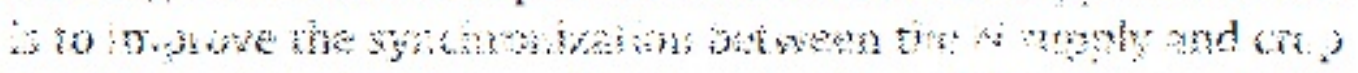

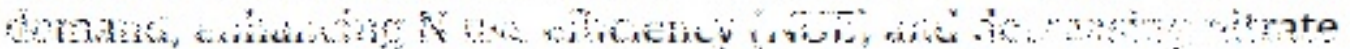

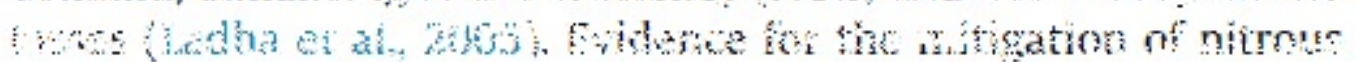

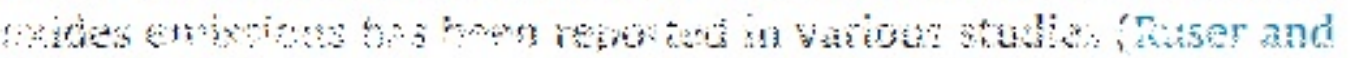

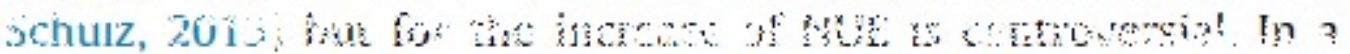

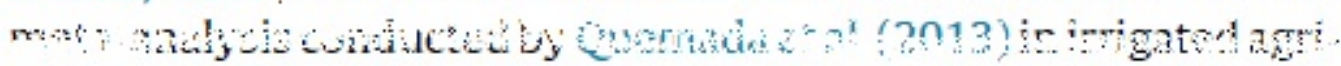

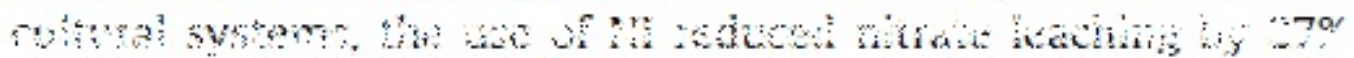

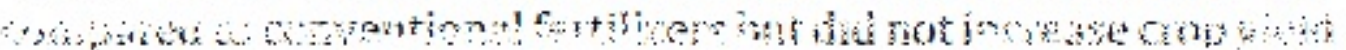

\footnotetext{
* Corresponding author.

E-mail address: miguel.quemada@upm.es (M. Quemada).
}

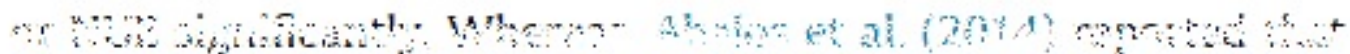

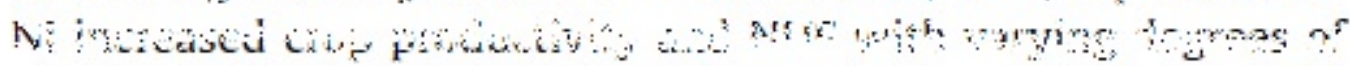

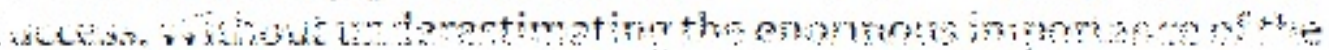

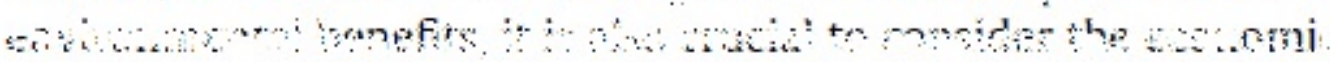

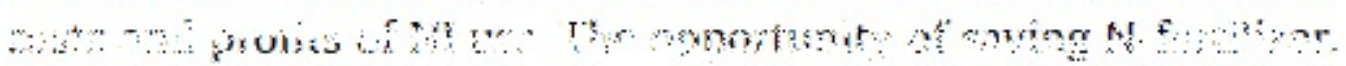

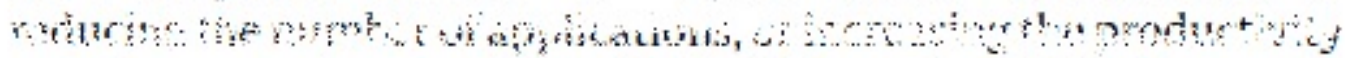

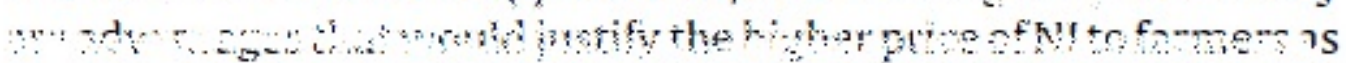

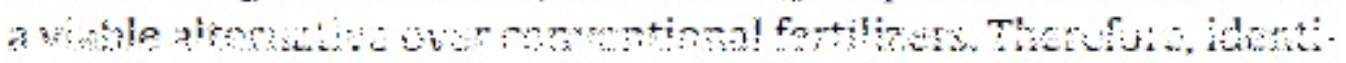

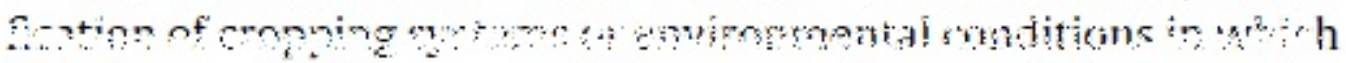

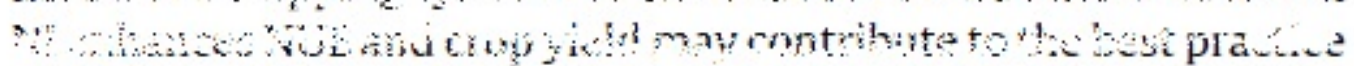

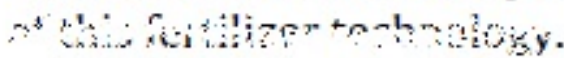

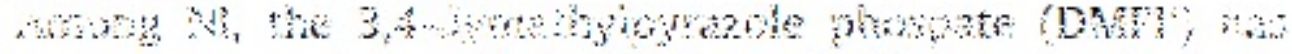

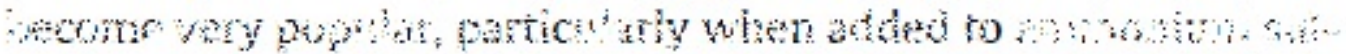

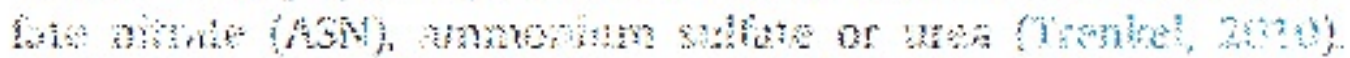

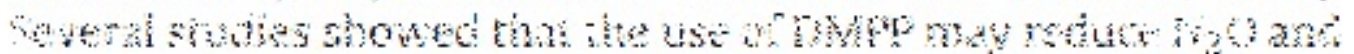

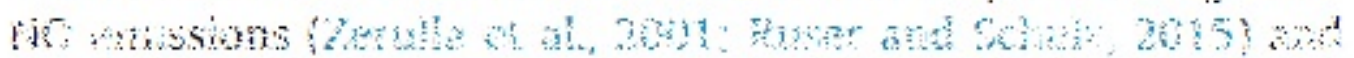

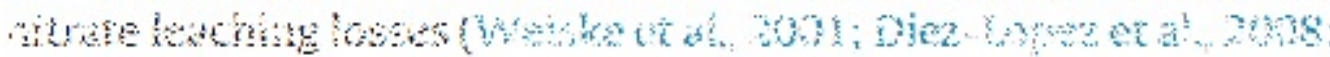

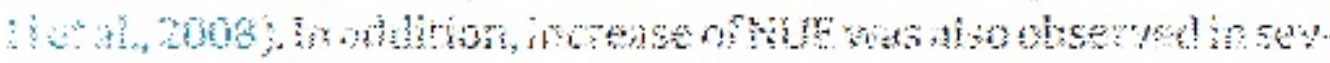
की 


\section{INTRODUCTION}

The application of nitrification inhibitors (NI) is a strategy to increase the efficiency of nitrogen $(\mathrm{N})$ in farming systems. These chemical compounds delay the conversion of ammonium to nitrate in soil by depressing the activity of nitrifiers bacteria. Consequently, when fertilizers pre-blended with NI are supplied the aim is to improve the synchronization between the $\mathrm{N}$ supply and crop demand, enhancing $\mathrm{N}$ use efficiency (NUE) and decreasing nitrate losses (Ladha et al., 2005). Evidence for the mitigation of nitrous oxides emissions has been reported in various studies (Ruser and Schulz, 2015) but for the increase of NUE is controversial. In a meta-analysis conducted by Quemada et al. (2013) in irrigated agricultural systems, the use of NI reduced nitrate leaching by $27 \%$ compared to conventional fertilizers but did not increase crop yield or NUE significantly. Whereas, Abalos et al. (2014) reported that NI increased crop productivity and NUE with varying degrees of success. Without underestimating the enormous importance of the environmental benefits, it is also crucial to consider the economic costs and profits of NI use. The opportunity of saving N-fertilizer, reducing the number of applications, or increasing the productivity are advantages that would justify the higher price of NI to farmers as a viable alternative over conventional fertilizers. Therefore, identification of cropping systems or environmental conditions in which NI enhances NUE and crop yield may contribute to the best practice of this fertilizer technology.

Among NI, the 3, 4 dymethylpyrazole phospate (DMPP) has become very popular, particularly when added to ammonium sulfate nitrate (ASN), ammonium sulfate or urea (Trenkel, 2010). Several studies showed that the use of DMPP may reduce $\mathrm{N}_{2} \mathrm{O}$ and NO emissions (Zerulla et al., 2001; Ruser and Schulz, 2015) and nitrate leaching losses (Weiske et al., 2001; Diez-Lopez et al., 2008; Li et al., 2008). In addition, increase of NUE was also observed in several studies (Diez-Lopez et al., 2008; Liu et al., 2013), but Arregui \& Quemada (2008) did not observe an effect in their wheat rainfed experiments. Results in terms of yield increase are also controversial. Pasda et al. (2001) observed an increase in yield and crop quality in cereals and vegetables when compared to conventional fertilizers; particularly pronounced at sites with risk of intensive rainfall or high application of irrigation water, and in light sandy soils. Liu et al. (2013) observed tendencies in crop yield, aboveground biomass and N uptake increase after application of DMPP blended with urea. As well, Martinez et al. (2015) observed a yield increase in strawberry plants. However, other authors did not observe significant response in yield when it was incorporated in the $\mathrm{N}$-fertilizer applied over winter and summer cereals (Weiske et al., 2001; Arregui and Quemada, 2008; Ercoli et al., 2013) or applied pre-blended with urea over grasslands (Menendez et al., 2009). These apparent contradictory results in yield and NUE reinforce that the effectiveness of NI depends on the cropping system, management strategies and soil or environment conditions (Barth et al., 2001; Wu et al., 2007). Abalos et al. (2014) concluded in a meta-analysis that the NI mean effect in fine-texture and alkaline soils was lower than in medium or coarse texture and acidic soils, but the effects on the specific experiments 
were highly variable. Thus more field experiments are needed in order to clarify the optimal conditions for NI application.

Most researchers focused on the annual effect of NI on crop yield or NUE and only a few studied the residual effect in the years following the application. In a 2-year experiment, Sharma and Prasad (1996) observed a cumulative effect in wheat grown after maize where DCD blended urea was applied: wheat yield was higher in the maize plots previously treated with DCD-urea than with conventional urea or control plots (no $\mathrm{N}$-fertilizer application). An effect on soil residual mineral $\mathrm{N}$ after harvest was more frequently reported. Wu et al. (2007) found that in a sandy loam soil, mineral $\mathrm{N}$ and $\mathrm{NH}_{4}{ }^{+}$-N concentration after harvest were greater in treatments where ammonium sulfate blended with DMPP was applied in comparison with conventional fertilizers. Wissemeier et al. (2001) observed that after an aerobic incubation in the laboratory, the $\mathrm{NH}_{4}{ }^{+}$recovered in soils treated with DMPP was higher than in those treated with other NI or without NI. Therefore, an evaluation of the cumulative effect of NI in crop yield and the possible relationship with the soil residual $\mathrm{N}$ is necessary.

The cumulative effect could be explained through $\mathrm{N}$ immobilization by microorganisms and fixation by soil clay minerals in non-exchangeable forms. The capacity of soils to fix $\mathrm{NH}_{4}{ }^{+}$is dependent mainly on soil characteristics and moisture conditions (Nieder et al., 2011). Fertilizer application increase $\mathrm{NH}_{4}{ }^{+}$fixation in wedges of clay minerals (Liang et al., 1999). This pool of recently fixed $\mathrm{NH}_{4}{ }^{+}$is more available to plants than native fixed $\mathrm{NH}_{4}{ }^{+}$, which is strongly retained and mostly not plant-available (Black and Waring, 1972). Regarding the use of NI, Juma and Paul (1983) noticed that $\mathrm{NH}_{4}{ }^{+}$ fixation was enhanced when 4-amino-1, 3, 4-triacole was applied. As well, Ma et al. (2015) noticed an increase of fixed $\mathrm{NH}_{4}{ }^{+}$when DMPP was added to urea.

On the other hand, the microbial biomass has a major role regulating soil $\mathrm{N}$ availability through the mineralization/immobilization processes. Some authors found an increase in the soil N microbial biomass after NI application (Juma and Paul, 1983). Addition of DMPP enhanced the availability of $\mathrm{NH}_{4}{ }^{+}$for microorganisms and increased $\mathrm{N}$ immobilization in a laboratory experiment (Ma et al., 2015). Moreover, the release of the immobilized $\mathrm{N}$ is closely related with the $\mathrm{NH}_{4}{ }^{+}$fixation/defixation processes. Some laboratory studies in the last years (Ma et al., 2015) emphasized the relationship between biotic and abiotic processes regulating $\mathrm{N}$ availability, though results needs to be clarified under field conditions.

Therefore, we hypothesized that the application of NI could increase the soil N supply capacity over time and contribute to an enhancement of N-recovery in the cropping system. The objectives of the study were to determine: (i) the effect of NI-fertilizers applied over maize during two seasons on grain yield, N content and NUE compared to conventional fertilizers, (ii) the soil residual effect of NI-fertilizers, assessed in a nonfertilized sunflower planted during a third season, and (iii) the possible sources of residual $\mathrm{N}$ via laboratory determinations. 


\section{MATERIALS AND METHODS}

\subsection{Field experiment}

The field experiment was conducted from 2013 to 2015 at the Chimenea research station, located in Aranjuez, Spain $\left(40^{\circ} 03^{\prime} \mathrm{N}, 03^{\circ} 31^{\prime} \mathrm{W}, 550 \mathrm{~m}\right.$ a.s.l.). The soil type is silty clay loam (Typic Calcixerept) with $\mathrm{pH}$ value $\sim 8$ thorough the soil profile, and low stone content (Gabriel and Quemada, 2011). Main soil properties are presented in Table 1. The climate is Mediterranean semi-arid with an annual rainfall of $415 \mathrm{~mm}$, mainly occurring in autumn and spring and almost negligible in summer, with mean annual temperature of $14.2{ }^{\circ} \mathrm{C}$. Weather data were recorded by a climatic station located $100 \mathrm{~m}$ from the field plot.

Table 1. Soil properties at the beginning of the experiment

\begin{tabular}{lllll}
\hline & \multicolumn{3}{c}{ Depth (cm) } \\
\hline $\mathrm{pH}(1: 2.5)$ & $0-23$ & $23-40$ & $40-70$ & $70-120$ \\
Organic Matter $\left(\mathrm{g} \mathrm{kg}^{-1}\right)$ & 8.2 & 8.1 & 8.0 & 7.8 \\
$\mathrm{CO}_{3}\left(\mathrm{~g} \mathrm{CO}_{3}^{2-} \mathrm{kg}^{-1}\right)$ & 31.8 & 29.2 & 21.9 & 22.3 \\
Sand $\left(\mathrm{g} \mathrm{kg}^{-1}\right)$ & 198.0 & 201.3 & 159.0 & 181.0 \\
Silt $\left(\mathrm{g} \mathrm{kg}^{-1}\right)$ & 260.0 & 250.0 & 250.0 & 250.0 \\
Clay $\left(\mathrm{g} \mathrm{kg}^{-1}\right)$ & 490.0 & 510.0 & 520.0 & 460.0 \\
\hline
\end{tabular}

In a $1080 \mathrm{~m}^{2}$ field experiment, fifteen plots $(12 \mathrm{~m}$ x $6 \mathrm{~m})$ were randomly distributed in five treatments, with three replications. In two treatments, ASN $(26 \% \mathrm{~N})$ together with the nitrification inhibitor DMPP (3, 4-dimethylpyrazole phosphate) was applied either at the recommended rate of $170 \mathrm{~kg} \mathrm{~N} \mathrm{ha}^{-1}$ (ENTEC-170), or with a reduced rate of $130 \mathrm{~kg}$ $\mathrm{N}^{-1}{ }^{-1}$ (ENTEC-130). In two other treatments, ASN conventional fertilizer was applied with the same rates (ASN-170, ASN-130). A control treatment without $\mathrm{N}$ application was included. The recommended rate of $170 \mathrm{~kg} \mathrm{~N}^{-1}$ was based on previous $\mathrm{N}$ response trials conducted in the same research field (Quemada et al., 2014). Fertilizers were applied over a maize crop (Zea mays L., Pioneer P1574, cycle 700) in 2013 and 2014. In 2015, a sunflower crop (Helianthus annuus L.) was planted in the same plots but without the application of $\mathrm{N}$ fertilizers, in order to test the cumulative residual effect. The crop preceding the maize 2013 was sunflower that did not receive fertilization. In 2013 and 2014, before sowing the maize, $30 \mathrm{~kg} \mathrm{P} \mathrm{ha}^{-1}$ and $100 \mathrm{~kg} \mathrm{~K} \mathrm{ha}^{-1}$ were applied to all plots to ensure $\mathrm{P}$ and $\mathrm{K}$ availability. In 2015, no pre-sowing fertilization was applied.

Year after year, crops were established in the same plots. Maize was sown in April and harvested in late September or early October at a seeding rate of 80,000 seeds $\mathrm{ha}^{-1}$ (in rows separated $0.74 \mathrm{~m}$ and spaced $0.17 \mathrm{~m}$ within rows) with a no-till seeder. Fertilizer treatments were broadcast by hand over maize in one application at the end of May, when the crop had four fully unfolded leaves which correspond to the growth stage 14 (GS-14) of the decimal scale (Lancashire et al., 1991). Sunflower was planted in late April at the same seeding rate as maize, and harvested in early September. Irrigation water was delivered using a sprinkler system $\left(12 \times 12 \mathrm{~m}^{2}\right)$. The irrigation 
schedule and doses were estimated from the daily values of crop evapotranspiration (ETc). This was calculated as $\mathrm{ETc}=\mathrm{Kc} \times \mathrm{ET}_{0}$, where $\mathrm{ET}_{0}$ is the reference evapotranspiration calculated by the FAO Penman-Monteith model (Allen et al. 1998) using daily local data. The crop coefficient $(\mathrm{Kc})$ for maize was obtained following the relationship proposed by Martinez-Cob (2008) in semiarid conditions, and for sunflower Kc was obtained based on Allen et al. (1998). In 2013 and 2014, total water input was $\sim 8 \%$ larger than the ETc to ensure a leaching fraction and avoid an increase on soil salinity, while in 2015 the irrigation was adjusted to sunflower needs (Table 2). During the intercropping period plots stayed as bare soil and did not receive any treatment nor labor.

Table 2. Cumulative reference evapotranspiration $\left(\mathrm{ET}_{0}\right)$, crop evapotranspiration (ETc), irrigation, precipitation, and the ratio of total water input and ETc. Values calculated for the period from the planting date to the physiological maturity of maize (2013 and 2014) and full flowering of sunflower (2015)

\begin{tabular}{llll}
\hline$(\mathrm{mm})$ & 2013 & 2014 & 2015 \\
\hline $\mathrm{ET}_{0}$ & 692.0 & 769.0 & 445.3 \\
$\mathrm{ETc}$ & 572.6 & 679.5 & 297.5 \\
Irrigation & 540.0 & 688.0 & 265.5 \\
Precipitation & 75.4 & 48.5 & 27.7 \\
Total water input / ETc & 1.1 & 1.1 & 1.0 \\
\hline
\end{tabular}

\subsection{Crop analysis: yield, grain quality, $N$ content and nutritional status of the crop}

For the 2013 and 2014 maize crop, the harvest index (grain/ (grain + rest of aboveground biomass)) was calculated before harvest. A 1-m stripe next to the central row was harvested by hand and separated into plant components (grain vs. rest of aboveground biomass), and a subsample of each component was oven-dried $\left(65^{\circ} \mathrm{C}\right)$ and weighed. At harvest, two $8 \mathrm{~m}$-stripe of the central rows from each plot were harvested by an experimental combiner and maize yield was recorded. A grain subsample was oven-dried $\left(65^{\circ} \mathrm{C}\right)$, weighed and ground. The rest of the aboveground biomass was calculated from the grain yield and the harvest index. A subsample of each plant component was used to determine total $\mathrm{N}$ concentration by the Dumas combustion method (LECO FP-428 analyzer, St. Joseph, MI, USA). For each plot, the N content of each crop component was calculated by multiplying its dry biomass by its $\mathrm{N}$ concentration and adding up both to obtain the $\mathrm{N}$ uptake. Anticipating the sunflower damage caused by birds before harvest, a sampling was performed in July $17^{\text {th }}, 2015$ at the flowering stage (GS-65), when maximum N uptake was expected (Gachon, 1972). Three 1-m strip per plot were hand harvested and separated (head vs. stem and leaves). Both components were weighed, ground, and a subsample was oven-dried $\left(65{ }^{\circ} \mathrm{C}\right)$. Similarly to maize, total $\mathrm{N}$ concentration was determined by the Dumas combustion method in each component, and $\mathrm{N}$ uptake was calculated.

Each year, crop N state was evaluated with SPAD $502^{\circledR}$ (Konica Minolta Inc., Japan), chlorophyll meter that measures leaf greenness. Readings were carried out at three different growth stages: stem elongation (GS-32), inflorescence emergence (GS-53), 
and full flowering (GS-69). On each sampling date, 12 measurements were taken from the uppermost fully developed leaf of twelve representative plants in the two central rows of each plot. The representative value of each plot was obtained as the average of the twelve readings.

\section{3. $N$ efficiency parameters}

Two components of the $\mathrm{N}$ use efficiency were calculated for each experimental season: agronomic efficiency $\left(A E_{N}\right)$ and the $\mathrm{N}$ recovery efficiency $\left(\mathrm{RE}_{\mathrm{N}}\right)$. The $\mathrm{AE}_{\mathrm{N}}$ refers to the $\mathrm{kg}$ of crop yield increase obtained per $\mathrm{kg}$ of $\mathrm{N}$ applied, i.e. the ratio of the difference between the grain yield of a treatment and the average grain yield of the control, to the $\mathrm{N}$ fertilizer applied in the specific treatment. The $\mathrm{RE}_{\mathrm{N}}$ refers to the $\mathrm{kg}$ of crop $\mathrm{N}$ uptake per $\mathrm{kg}$ of $\mathrm{N}$ applied, calculated as the ratio of the difference between the crop $\mathrm{N}$ uptake by a treatment and the average crop $\mathrm{N}$ uptake by the control, to the $\mathrm{N}$ fertilizer applied. Furthermore, the total $\mathrm{RE}_{\mathrm{N}}$ during the whole experimental period was calculated for each treatment based on the crop $\mathrm{N}$ uptake during the three seasons.

\subsection{Soil inorganic $N$ content $\left(N_{\min }\right)$}

Each year, before crop sowing and after harvesting, soil nitrate and ammonium content were determined. Two soil cores were taken from each plot to $1 \mathrm{~m}$ depth by $0.2 \mathrm{~m}$ intervals, and were combined by depth to provide a composite profile of five samples. Soil samples were placed in a plastic box and firmly closed immediately, transported and refrigerated $\left(4-6{ }^{\circ} \mathrm{C}\right)$. Within the five consecutive days a soil subsample of each box was extracted with $1 \mathrm{M} \mathrm{KCl} \mathrm{(} \mathrm{30} \mathrm{g} \mathrm{of} \mathrm{soil:} 150 \mathrm{ml}$ of $\mathrm{KCl})$, centrifuged, decanted, and a subsample of the supernatant volume was stored in a freezer until later analysis. Nitrate concentration was determined by the Griess-Ilosvay method and $\mathrm{NH}_{4}{ }^{+}$by the salicylatehypochlorite method. Soil $\mathrm{N}_{\min }$ was calculated for each layer and plot.

\subsection{Residual effect of the NI fertilizers}

In order to elucidate and locate the hypothetical residual effect of ENTEC fertilizers, the soil $\mathrm{N}$ mineralization potential $\left(\mathrm{N}_{0}\right)$ and the soil non-exchangeable $\mathrm{NH}_{4}{ }^{+}\left(\mathrm{NH}_{4}{ }_{\mathrm{f}}^{+}\right)$were determined two years after the starting of the experiment. Before sowing sunflower in April 2015, soil samples were collected to $60 \mathrm{~cm}$ depth by $0.2 \mathrm{~m}$ intervals from each plot. Soils were cleaned from residue contamination and air-dried. Subsamples corresponding to the top layer samples $(0-0.2 \mathrm{~m})$ were $2 \mathrm{~mm}$ sieved and used to determine $\mathrm{N}_{0}$ in an aerobic incubation according to a modification of the method proposed by Stanford and Smith (Stanford and Smith, 1972; Alonso-Ayuso et al., 2014). In a plastic syringe (3.5 cm diameter, $10 \mathrm{~cm}$ long), a homogeneous mixture of soil (30 g) and sand (30 g) was sandwiched between thin glass wool layers to avoid soil losses during leaching and minimize moisture losses. Initial soil inorganic $\mathrm{N}$ was removed by leaching with $100 \mathrm{ml}$ of $0.01 \mathrm{M} \mathrm{CaCl}_{2}$, followed by $20 \mathrm{ml}$ of a $\mathrm{N}$-free nutrient solution $\left(0.0095 \mathrm{M} \mathrm{CaSO}_{4}, 0.000047 \mathrm{M} \mathrm{KH}_{2} \mathrm{PO}_{4}, 0.00138 \mathrm{M} \mathrm{K}_{2} \mathrm{SO}_{4}, 0.0003 \mathrm{M}\right.$ $\mathrm{MgSO}_{4}$ ). The excess of water was removed using vacuum. Soil water was maintained at 
$60 \%$ water-filled pore space and allowed to fluctuate during the experiment $\pm 3 \%$. The syringes were covered with a porous parafilm, and incubated aerobically at $35{ }^{\circ} \mathrm{C}$. Syringes were removed from the incubator at 14, 28, 42, 56, and $70 \mathrm{~d}$ after preparation, and were leached with $100 \mathrm{ml}$ of $0.01 \mathrm{M} \mathrm{CaCl}_{2}$ solution, followed by $20 \mathrm{ml}$ of $\mathrm{N}$-free solution. Leachates were made up to $100 \mathrm{ml}$ with $0.01 \mathrm{M} \mathrm{CaCl}_{2}$ and subsamples were stored in a freezer at $-25{ }^{\circ} \mathrm{C}$ until later analysis. After the leaching procedure, the cores were allowed to drain under vacuum until a weight within $3 \%$ of that measured at the beginning of the experiment was achieved. Nitrate and ammonium concentration in the leachates were determined by the methods mentioned before. The $\mathrm{N}_{0}$ and the mineralization rate constant $(\mathrm{k})$ were estimated after fitting a non-linear regression model $\left(\mathrm{Nt}=\mathrm{N}_{0} \exp (-\mathrm{kt})\right.$ ) for describing cumulative $\mathrm{N}$ mineralized $(\mathrm{Nt})$ with time $(\mathrm{t})$ in each soil sample.

The $\mathrm{NH}_{4}{ }_{\mathrm{f}} \mathrm{f}$ extraction was carried out according to the modified method proposed by Liang et al. (1999). Air-dried samples from the 0-20, 20-40 and 40-60 cm soil layers from each plot were finely sieved $(<0.15 \mathrm{~mm})$. Two subsamples of $0.5 \mathrm{~g}$ from each soil sample were treated with an alkaline potassium hypobromite solution to remove exchangeable $\mathrm{NH}_{4}^{+}$and organic $\mathrm{N}$, boiled for $5 \mathrm{~min}$, centrifuged and decanted. Soil residues from this pre-treatment were washed three times with $0.5 \mathrm{M} \mathrm{KCl}$, shaken, centrifuged and then decanted and oven-dried $\left(105^{\circ} \mathrm{C}\right)$. In all subsamples, the nonexchangeable $\mathrm{N}_{-} \mathrm{NH}_{4}{ }^{+}$concentration was determined by the Dumas combustion method and the delta ${ }^{15} \mathrm{~N}$ by mass spectrophotometry (Europa Scientific 20-20 IRMS Analyzer $^{\circledR}$, Crewe, UK).

\subsection{Statistical analysis}

To determine differences between the five treatments for crop data, soil $\mathrm{N}_{\min }$ and laboratory determinations, one-way analysis of variance (ANOVA) was performed separately for each year. For the NUE components, the control treatment was used to perform the calculations, and the four fertilized treatments were compared to each other. Therefore, in this case differences among the two components of NUE were tested by ANOVA two-way factorial analysis including as factors: fertilizer type and rate. Data normality and variance homogeneity were verified before the analysis. Means were separated by Duncan's test at 0.05 probability level $(\mathrm{P} \leq 0.05)$. The $\mathrm{N}$ mineralization potential model was fitted to the cumulative $\mathrm{N}$ mineralized using a non-linear regression procedure. All statistical analyses were performed using the StatGraphics Centurion XVI software (StatPoint Technologies Inc, Warrenton, VA, USA).

\section{RESULTS}

\subsection{Crop analysis: yield, grain quality, $N$ content and nutritional status of the crop}

Grain yield, $\mathrm{N}$ content and $\mathrm{N}$ uptake by crops were affected by treatments; although differences were more pronounced in the second year (Table 3). The first year, differences in maize yield were not clear between treatments, except for the ASN-170 that had higher yield than the control. The second year, treatments fertilized with the 
recommended rate or the reduced rate with ENTEC had higher yield $\left(10.8 \mathrm{Mg} \mathrm{ha}^{-1}\right.$ on average) than the control $\left(5 \mathrm{Mg} \mathrm{ha}^{-1}\right)$ and the reduced rate with conventional fertilizer. The last year, at the time of full flowering, sunflower in plots previously fertilized with ENTEC-170 had the highest head biomass value. ASN-170 and ENTEC-130 treatments had also higher head biomass than the control but no differences were found between them (Table 4).

Table 3. Grain yield, grain $\mathrm{N}$ concentration and grain $\mathrm{N}$ content, crop $\mathrm{N}$ uptake, and the $\mathrm{N}$ agronomic efficiency $\left(\mathrm{AE}_{\mathrm{N}}\right)$ f the maize crop in the two years of the research

\begin{tabular}{|c|c|c|c|c|c|}
\hline \multirow{3}{*}{ Treatment } & \multicolumn{3}{|c|}{ Grain } & \multicolumn{2}{|c|}{ Crop } \\
\hline & $\begin{array}{l}\text { Yield } \\
\text { Mg ha }^{-1}\end{array}$ & $\begin{array}{l}\text { N concentration } \\
\%\end{array}$ & $\begin{array}{l}\mathrm{N} \text { content } \\
\mathrm{kg} \mathrm{N} \mathrm{ha}^{-1}\end{array}$ & $\begin{array}{l}\text { N uptake } \\
\mathrm{kg} \mathrm{N} \mathrm{ha}^{-1}\end{array}$ & $\begin{array}{l}\mathrm{AE}_{\mathrm{N}} \\
\text { kg grain kg N}{ }^{-1}\end{array}$ \\
\hline & \multicolumn{5}{|c|}{2013} \\
\hline Control & $6.4 \mathrm{~b}$ & $1.16 \mathrm{~b}$ & $74.6 \mathrm{~b}$ & $107.9 \mathrm{~b}$ & \\
\hline ASN- 130 & $8.6 \mathrm{ab}$ & $1.34 \mathrm{a}$ & $115.8 \mathrm{a}$ & $168.2 \mathrm{a}$ & $16.72 \mathrm{a}$ \\
\hline ASN- 170 & $10.0 \mathrm{a}$ & $1.34 \mathrm{a}$ & $134.4 \mathrm{a}$ & $212.3 \mathrm{a}$ & $21.18 \mathrm{a}$ \\
\hline ENTEC-130 & $9.1 \mathrm{ab}$ & $1.37 \mathrm{a}$ & $125.3 \mathrm{a}$ & $191.6 \mathrm{a}$ & $20.68 \mathrm{a}$ \\
\hline \multirow[t]{2}{*}{ ENTEC-170 } & $9.7 \mathrm{ab}$ & $1.34 \mathrm{a}$ & $129.4 \mathrm{a}$ & $190.4 \mathrm{a}$ & $19.24 \mathrm{a}$ \\
\hline & \multicolumn{5}{|c|}{2014} \\
\hline Control & $5.0 \mathrm{c}$ & $1.14 \mathrm{~b}$ & $55.8 \mathrm{~b}$ & $69.1 \mathrm{c}$ & \\
\hline ASN- 130 & $7.6 \mathrm{~b}$ & $1.12 \mathrm{~b}$ & $85.9 \mathrm{~b}$ & $114.1 \mathrm{bc}$ & $20.73 \mathrm{c}$ \\
\hline ASN- 170 & $10.7 \mathrm{a}$ & $1.15 \mathrm{~b}$ & $123.4 \mathrm{a}$ & $162.8 \mathrm{ab}$ & $33.93 \mathrm{~b}$ \\
\hline ENTEC-130 & $11.3 \mathrm{a}$ & $1.33 \mathrm{ab}$ & $150.7 \mathrm{a}$ & $186.4 \mathrm{a}$ & $48.93 \mathrm{a}$ \\
\hline ENTEC-170 & $10.6 \mathrm{a}$ & $1.46 \mathrm{a}$ & $154.8 \mathrm{a}$ & $196.2 \mathrm{a}$ & $33.07 \mathrm{~b}$ \\
\hline
\end{tabular}

Within year, treatments followed by different letter are significantly different at $\mathrm{P} \leq 0.05$ by Duncan's test.

Table 4. Head biomass, $\mathrm{N}$ concentration, $\mathrm{N}$ content and $\mathrm{N}$ uptake in sunflower at flowering

\begin{tabular}{lllll}
\hline \multirow{2}{*}{ Treatment } & $\begin{array}{l}\text { Head } \\
\text { biomass }\end{array}$ & $\begin{array}{l}\text { Head N } \\
\text { concentration }\end{array}$ & $\begin{array}{l}\text { Head } \\
\text { N content }\end{array}$ & $\begin{array}{l}\text { Crop } \\
\text { N uptake }\end{array}$ \\
\cline { 2 - 5 } & $\mathrm{Mg} \mathrm{ha}^{-1}$ & $\%$ & $\mathrm{~kg} \mathrm{~N} \mathrm{ha}^{-1}$ & $\mathrm{~kg} \mathrm{~N} \mathrm{ha}^{-1}$ \\
\hline Control & $0.7 \mathrm{~d}$ & 1.77 & $12.4 \mathrm{~d}$ & $25.6 \mathrm{~d}$ \\
ASN- 130 & $1.4 \mathrm{~cd}$ & 1.77 & $23.1 \mathrm{~cd}$ & $50.5 \mathrm{c}$ \\
ASN- 170 & $2.4 \mathrm{ab}$ & 1.63 & $38.3 \mathrm{ab}$ & $79.2 \mathrm{~b}$ \\
ENTEC-130 & $2.1 \mathrm{bc}$ & 1.64 & $33.9 \mathrm{bc}$ & $72.5 \mathrm{~b}$ \\
ENTEC-170 & $3.3 \mathrm{a}$ & 1.55 & $51.1 \mathrm{a}$ & $100.0 \mathrm{a}$ \\
\hline
\end{tabular}

Within year, treatments followed by different letter are significantly different at $\mathrm{P} \leq 0.05$ by Duncan's test.

In 2013, the grain $\mathrm{N}$ concentration was larger for the fertilized treatments $(1.35 \%)$ than for the control (1.16\%) (Table 3). In 2014, the ENTEC-170 treatment had higher grain $\mathrm{N}$ concentration $(1.46 \%)$ than the control and the ASN treatments. No differences were observed in 2015 (Table 4). The first season, the grain $\mathrm{N}$ content in the control was the lowest, but no differences were found between the other treatments. However, in 2014, differences between fertilized treatments were observed: those with the recommended rate and ENTEC with the reduced rate had greater grain $\mathrm{N}$ content than the ASN-130 and the control.

In 2013, the $\mathrm{N}$ uptake was higher in the fertilized plots than in the control and no effect due to fertilizer rate or type was observed (Table 3). In 2014, the $\mathrm{N}$ uptake was higher in both ENTEC and ASN-170 treatments than in the control, being the ASN-130 in between. The last year, the ENTEC-170 treatment had the highest sunflower N uptake. 
ENTEC-130 and ASN-170 formed a subgroup below and no differences were observed between them (Table 4). SPAD readings were affected by treatment and sampling time (Table 5). In 2013, at the inflorescence emergence stage (GS-53), treatments that received the recommended rate achieved greater SPAD readings, and at full flowering all the fertilized treatments achieved higher values than the control. In 2014, ENTEC treatments together with ASN-170 had higher SPAD readings than the control and ASN-130 at full flowering. The third year, readings in the non fertilized sunflower leaves were higher for ENTEC than for the control at GS-53, while at full flowering, no differences between treatments were observed.

Table 5. SPAD readings at different growth stages of maize and sunflower

\begin{tabular}{|c|c|c|c|}
\hline & \multicolumn{3}{|l|}{ SPAD readings } \\
\hline & Maize $1^{\text {st }}$ year & Maize $2^{\text {nd }}$ year & Sunflower \\
\hline \multicolumn{4}{|c|}{ Inflorescence emergence, heading (GS-53) } \\
\hline Control & $43.3 \mathrm{c}$ & $40.03 \mathrm{a}$ & $33.23 \mathrm{~b}$ \\
\hline ANS-130 & $46.2 \mathrm{~b}$ & $41.17 \mathrm{a}$ & $37.53 \mathrm{ab}$ \\
\hline ANS-170 & $48.8 \mathrm{a}$ & $42.67 \mathrm{a}$ & $38.00 \mathrm{ab}$ \\
\hline ENTEC-130 & $46.2 \mathrm{~b}$ & $42.47 \mathrm{a}$ & $40.13 \mathrm{a}$ \\
\hline ENTEC-170 & $50.1 \mathrm{a}$ & $40.80 \mathrm{a}$ & $40.37 \mathrm{a}$ \\
\hline \multicolumn{4}{|c|}{ Full flowering (GS-69) } \\
\hline Control & $38.93 \mathrm{c}$ & $29.5 \mathrm{~b}$ & $30.47 \mathrm{a}$ \\
\hline ANS-130 & $43.77 \mathrm{~b}$ & $30.8 \mathrm{~b}$ & $34.22 \mathrm{a}$ \\
\hline ANS-170 & $47.58 \mathrm{ab}$ & $36.1 \mathrm{a}$ & $31.17 \mathrm{a}$ \\
\hline ENTEC-130 & $47.33 \mathrm{ab}$ & $36.9 \mathrm{a}$ & $32.38 \mathrm{a}$ \\
\hline ENTEC-170 & $48.57 \mathrm{a}$ & $35.7 \mathrm{a}$ & $33.35 \mathrm{a}$ \\
\hline
\end{tabular}

Within year, treatments followed by different letter are significantly different at $\mathrm{P} \leq 0.05$ by Duncan's test.

\section{2. $N$ efficiency parameters}

The treatment effect on the fertilizer use efficiency showed up during the second year of the experiment (Fig. 1; Table 3). In 2013, no differences between treatments or factors were found. The average $\mathrm{AE}_{\mathrm{N}}$ was $\sim 20 \mathrm{~kg}$ grain $\mathrm{kg}^{-1} \mathrm{~N}$ and the $\mathrm{RE}_{\mathrm{N}} \sim 55 \%$. In 2014, the factor fertilizer type was significant and fertilizers with $\mathrm{NI}$ increase $\mathrm{AE}_{\mathrm{N}}$ compared to conventional fertilizers. ENTEC with the reduced rate was the more efficient treatment and the $\mathrm{AE}_{\mathrm{N}}$ was $49 \mathrm{~kg}$ grain $\mathrm{kg}^{-1} \mathrm{~N}$ applied, higher than the treatments with the recommended rate, and double that ASN-130. The effect of the fertilizer type on $\mathrm{RE}_{\mathrm{N}}$ was significant on 2014 and for the whole experiment period. In 2014, the $\mathrm{RE}_{\mathrm{N}}$ in the maize fertilized with ENTEC was $>74 \%$ whereas the average of conventional fertilizer treatments was $\sim 45 \%$ (Fig. 1). The average $\mathrm{RE}_{\mathrm{N}}$ during the whole experimental period for the ENTEC treatments was $91 \%$, whereas the ASN treatments recovered $63 \%$ of the $\mathrm{N}$ applied with fertilizers the previous years (Fig. 1). 


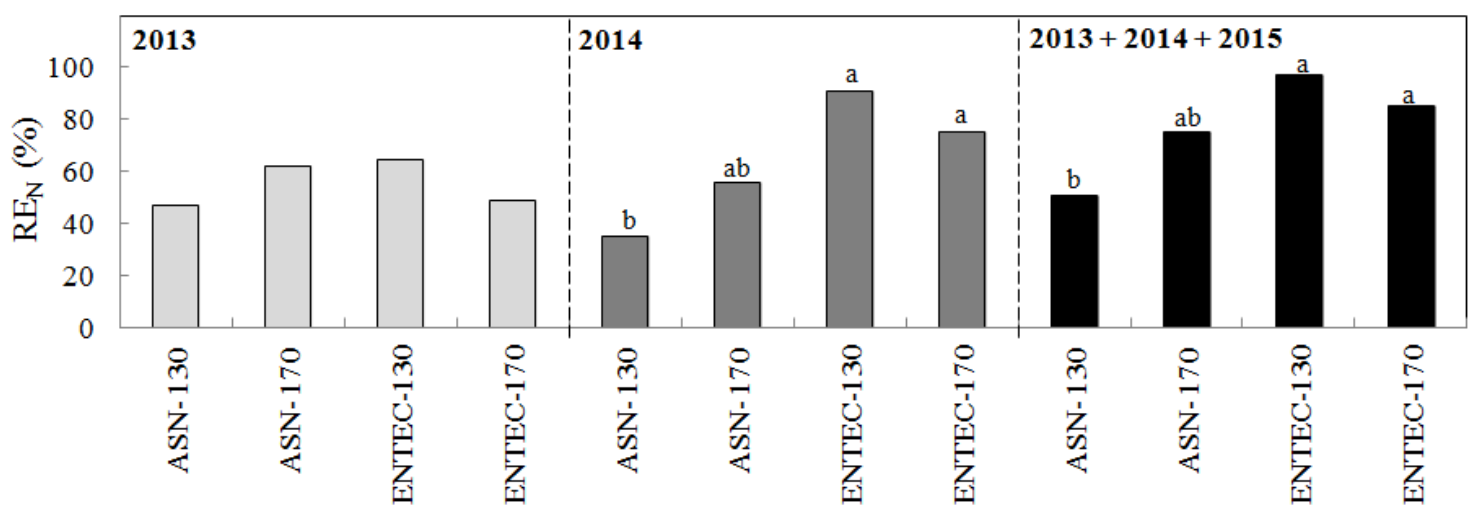

Fig. 1. Nitrogen recovery efficiency $\left(R_{\mathrm{N}}\right)$ as affected by fertiliser treatment in 2013, 2014; and cumulative $N$ recovery over the three experimental seasons $(2013+201+2015)$. Letters above bars represent differences between treatments at $\mathrm{P} \leq 0.05$ by Duncan's test.

\subsection{Soil inorganic $N$ content}

At the beginning of the experiment, in April 2013, the soil inorganic $\mathrm{N}$ content in $1 \mathrm{~m}$ depth was $\sim 125 \mathrm{~kg} \mathrm{~N} \mathrm{ha}^{-1}$, with $\sim 30 \%$ located in the soil upper $40 \mathrm{~cm}$ (Fig. 2). Six months later, at maize harvest, $\mathrm{N}_{\min }$ decreased. In April 2014, ENTEC at the recommended rate accumulated more $\mathrm{N}_{\min }$ than the control in the profile, because of the high content in the $80-100 \mathrm{~cm}$ soil layer. This accumulation in the deepest layer was observed in the following samplings. After the maize season, it was remarkable that ENTEC-170 increased $N_{\min }$ in the upper layer. Before sunflower sowing, ENTEC at the recommended rate had the greatest $\mathrm{N}_{\min }$ in the profile, being differences significant in the 0-20 and 20-40 cm layers. At sunflower harvest, the mineral $\mathrm{N}$ content in the soil profile was similar in all treatments $\left(\sim 41 \mathrm{~kg} \mathrm{~N} \mathrm{ha}^{-1}\right)$ and layers below $40 \mathrm{~cm}$ were depleted.

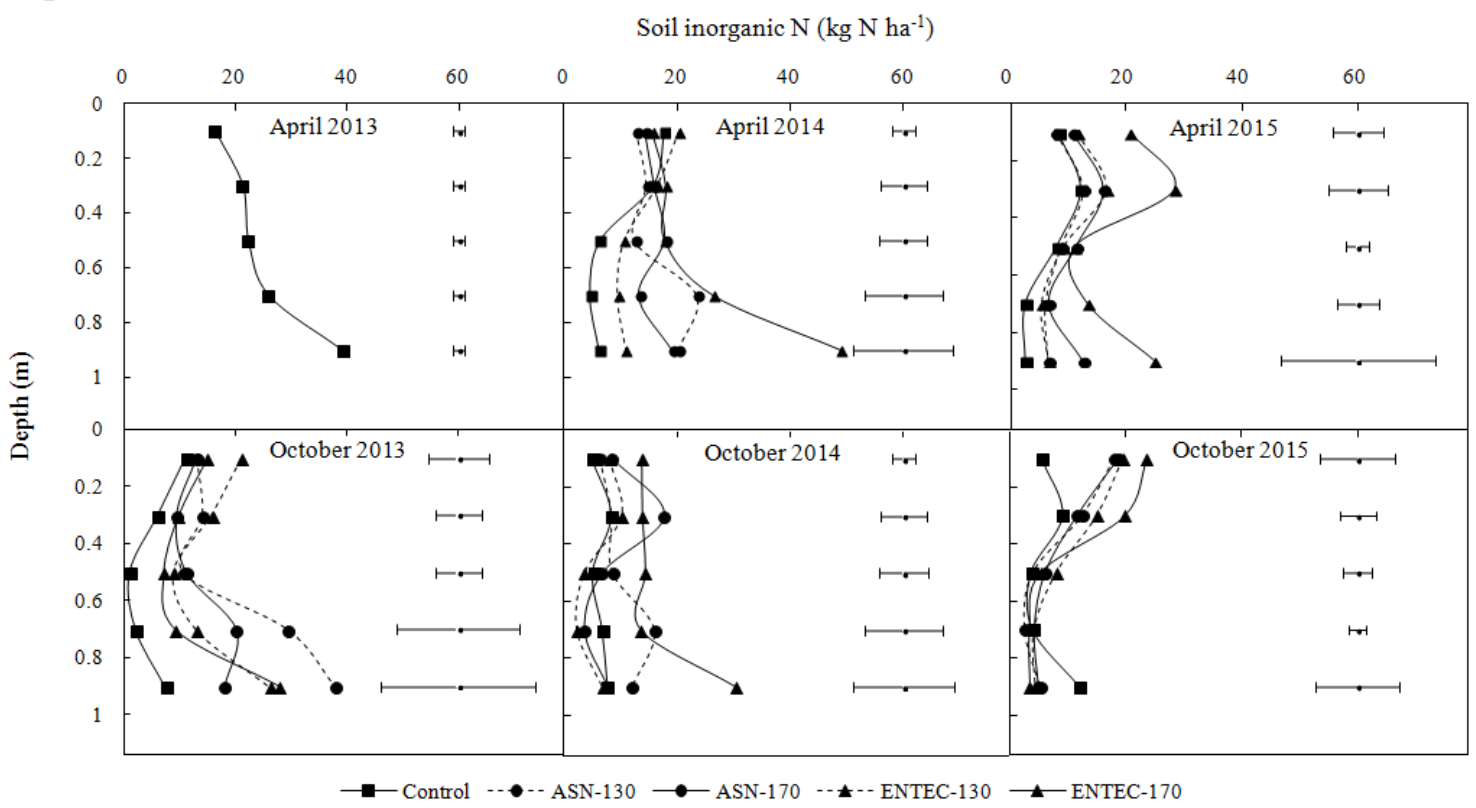

Fig. 2. Soil inorganic $\mathrm{N}$ in the upper $1 \mathrm{~m}$ of the soil profile for each treatment at different sampling times. In April 2013, separate bars indicate the standard error of the mean at each depth. In the other subplots, separate bars indicate the range of $\operatorname{LSD}(t=0.05)$ for treatments at each depth. 


\subsection{Residual effect of the NI fertilizers}

After 10 weeks of the aerobic incubation under controlled conditions, the soil samples from the ENTEC-170 treatment accumulated more $\mathrm{N}_{\min }$ than samples from the control (Fig. 3). No differences were observed in the mineralization rates obtained by fitting the one-pool exponential model, but the soil $\mathrm{N}$ mineralization potential was higher for the ENTEC-170 than for the ASN-170 and control treatments.

The $\mathrm{NH}_{4}{ }_{\mathrm{f}}^{+}$content of the samples ranged between 0.011 and $0.014 \%$, equivalent to $100-140 \mathrm{mg} \mathrm{N} \mathrm{kg}^{-1}$. The detection threshold of the analyzer was $0.005 \% \mathrm{~N}$, therefore no reliable differences between treatments in the content of $\mathrm{NH}_{4}{ }_{\mathrm{f}}^{+}$were detected. In the soil from 40-60 cm depth, delta ${ }^{15} \mathrm{~N}-\mathrm{NH}_{4}{ }_{\mathrm{f}}$ values were higher for ENTEC treatment and the ASN with the recommended rate (Fig. 4).

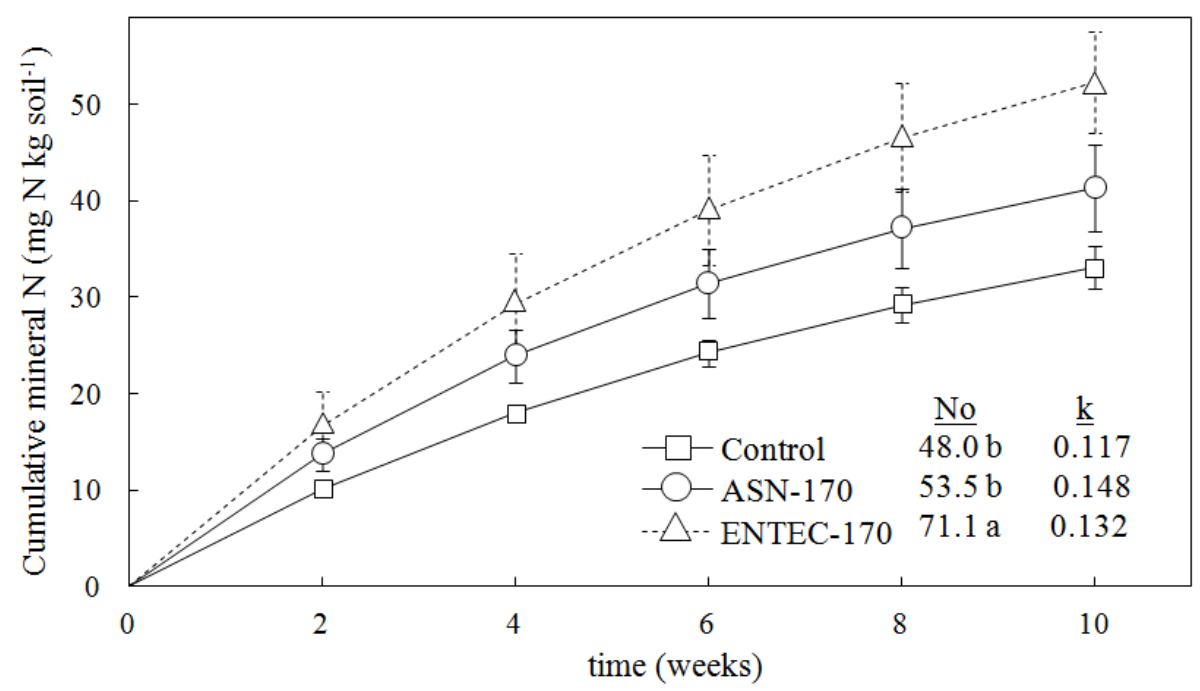

Fig. 3. Cumulative $\mathrm{N}$ mineralization in soils from the control, ASN-170 and ENTEC-170 treatments during a 10-week aerobic incubation. Soil $\mathrm{N}$ mineralization potential $\left(\mathrm{N}_{0}\right)$ and $\mathrm{N}$ mineralization rate (k) were calculated by fitting a non-linear regression model $\left(\mathrm{Nt}=\mathrm{N}_{0} \exp (-\mathrm{k} t)\right)$. Bars represent the standard error.

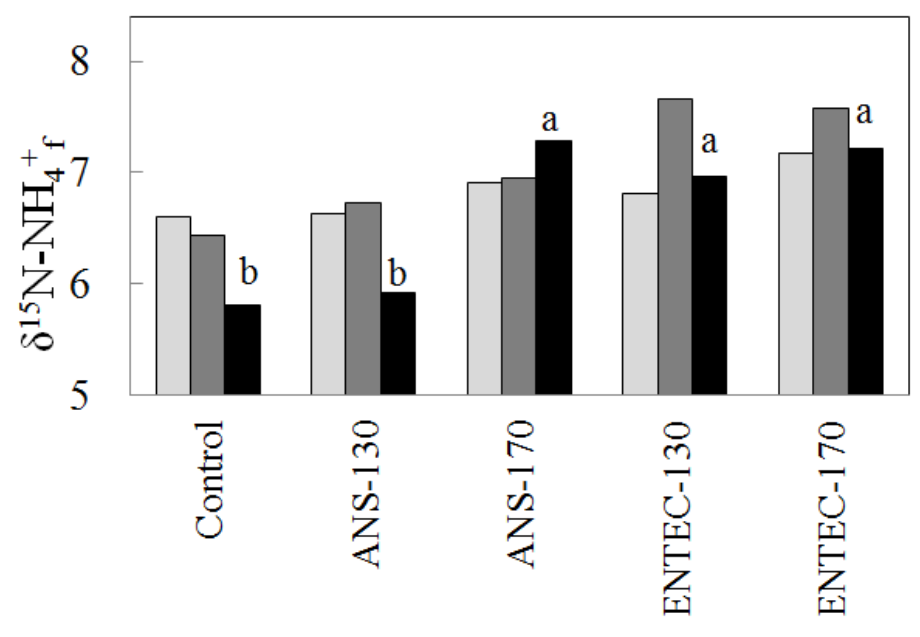

$\square 0-20 \mathrm{~cm} \quad \square 20-40 \mathrm{~cm} \quad \square 0-60 \mathrm{~cm}$

Fig. 4. Non-exchangeable ammonium $\left(\delta^{15} \mathrm{~N}_{-} \mathrm{NH}_{4}{ }_{\mathrm{f}}^{+}\right)$measured for each treatment at different soil depths two years after fertilizer application. Different letters above bars show differences between treatments at each depth at $\mathrm{P} \leq 0.05$ by Duncan's test. 


\section{DISCUSSION}

We know that nitrification inhibitors technology may increase the recovery of $\mathrm{N}$ fertilizer applied to a crop by depressing the activity of nitrifiers bacteria during a few months after application (Pasda et al., 2001). Previous studies proved that much of this effect is due to reducing $\mathrm{NO}_{3}{ }^{-}$losses by leaching or denitrification during the cropping season (Ladha et al., 2005; Quemada et al., 2013). In the present study, we showed that fertilizers with a NI increased the NUE in the following year after application compared to a conventional fertilizer. This effect was probably due to the slow release of $\mathrm{NH}_{4}^{+}$ immobilized in the soil microbial biomass or fixed into non-exchangeable forms in clay minerals (Juma and Paul, 1983; Ma et al, 2015). This new information opens the opportunity to design strategies for increasing NUE at a cropping system level and reducing the recommended fertilizer rate when NI are applied.

In our experiment, the first year of fertilizer application there was not a clear effect of fertilizer type or rate on maize, probably due to the high soil initial content of mineral $\mathrm{N}$. The amount of mineral $\mathrm{N}$ present in the soil at planting $\left(125 \mathrm{~kg} \mathrm{~N} \mathrm{ha}^{-1}\right)$ plus the soil $\mathrm{N}$ mineralized during the cropping season masked the effect of $\mathrm{N}$ fertilizer and were enough to provide a high yield of the control treatment. Differences to the control appeared in $\mathrm{N}$ uptake, both in grain and total biomass, though the $\mathrm{AE}_{\mathrm{N}}$ and the $\mathrm{RE}_{\mathrm{N}}$ were not affected by fertilizer type or rate in the first year of the experiment. Other researchers reported that the effect of NI on crop productivity and NUE are highly variable the first year of application and depend on the environmental conditions and cropping systems. Particularly, several studies showed that DMPP enhanced NUE and crop productivity in cereals grown in coarse soils by reducing leaching (Diez-Lopez et al., 2008; Liu et al., 2013). In fine-texture soils, the effect of DMPP in mitigating gaseous emissions during the days following fertilizer application is relevant but on NUE and crop productivity the effect is often not significant (Diez-Lopez et al., 2008; Liu et al., 2013). Other authors reported non-effect of DMPP on NUE or cereal productivity in a silty clay loam soil with high content of available N (Arregui and Quemada, 2008). In general, the short term efficiency of NI is higher under conditions that favor high drainage, gaseous losses and high input of $\mathrm{N}$ fertilizer, whereas in our experiment intensive application of irrigation water was avoided and fertilizer rate was adjusted to crop needs.

The second year of the experiment, significant differences were found between treatments in the main crop variables. ENTEC treatments, together with the conventional fertilizer at the recommended rate $-170 \mathrm{~kg} \mathrm{~N} \mathrm{ha}^{-1}$ - achieved greater maize yield. Therefore, ENTEC would allow a $23 \%$ fertilizer rate reduction without decreasing yield. Our results were in agreement with those obtained by Sharma and Prasad (1996), the only study we found in the literature in which an effect on yield was reported in the crop following NI fertilizer application. They observed that in a maize/wheat rotation, wheat yield was higher in the maize plots previously treated with DCD-urea than with conventional urea or non $\mathrm{N}$ fertilized plots. Wheat was planted a few weeks after harvesting maize so the crop rotation lasted less than a year. 
The second year, treatments at the recommended rate had higher $\mathrm{N}$ concentration than ASN and the control treatment, being the ENTEC-130 treatment in between. This led to a higher $\mathrm{N}$ content in grain for ENTEC treatments and ASN-170. These results were supported by optical readings, indicators of the crop N nutritional status. The ASN-170 treatment showed greater SPAD values than the ASN-130 at the flowering stage. However, no differences were found between ENTEC treatments, and values were similar to ASN-170. Other authors observed an enhanced chlorophyll content in different crops supplied with fertilizers containing DMPP (Pasda et al., 2001). Concerning SPAD, Martinez et al. (2015) observed increasing values measured in strawberry leaves, on the treatment with fertilizer pre-blended with DMPP. Thus, in our conditions the NI enhanced grain yield and N uptake in 2014.

Both components of the NUE showed the effect of the treatments in the second year, rather than in the first. The $\mathrm{AE}_{\mathrm{N}}$ of the ENTEC-130 was the highest, and no differences were observed when the recommended rate was applied. By reducing the rate from 170 to $130 \mathrm{~kg} \mathrm{~N}^{-1}$ the $\mathrm{kg}$ of maize per $\mathrm{kg}$ of $\mathrm{N}$ applied with ENTEC increased in $44 \%$. For the conventional fertilizers the highest $\mathrm{AE}_{\mathrm{N}}$ corresponded to the recommended rate. The mean $\mathrm{AE}_{\mathrm{N}}$ reported for maize in the meta-analysis conducted by Lhada et al. (2005) was $21 \mathrm{~kg} \mathrm{~kg}^{-1}$ applied $\mathrm{N}$, being the $75 \%$ of the collected data between $15-33 \mathrm{~kg} \mathrm{~kg}^{-1}$. In our experiment the ENTEC and the ASN-170 treatments were in higher range, suggesting a residual effect from the previous year fertilizer. The $\mathrm{RE}_{\mathrm{N}}$ results strongly supported the residual effect of the fertilizers with NI in our experiment. The values obtained for all treatments in 2013 or for the ASN treatments in 2014 are on the ranges reported on the literature for maize: comparing to 39-64\% (Bundy and Andraski, 2005) or 40-51\% (Gabriel and Quemada, 2011). In the second year of our experiment, the ENTEC treatments allowed a higher recovery of the fertilizer-N applied. The $R_{N}$ ( $\sim 90 \%$ in the ENTEC-130 treatment) were higher than the reported in the literature suggesting a residual effect of NI. However, it was not possible to separate the year effect of NI and a possible residual effect in plots previously fertilized in 2013. The results obtained in 2015 in the non-fertilized sunflower planted in the same plots were crucial to determine if a cumulative effect existed. At the sunflower heading stage, SPAD readings were greater for ENTEC treatments than for the control. At full flowering, when $\mathrm{N}$ uptake had mostly occurred, ENTEC with the recommended rate showed the greatest N uptake. ENTEC-130 and ASN-170 formed a subgroup below, with no differences between them. As a consequence, when sunflower results were taken into account, a higher $\mathrm{RE}_{\mathrm{N}}$ for the whole experiment $(2013 \rightarrow 2015)$ was observed for ENTEC treatments and the cumulative effect of NI was clearly showed.

The cumulative effect of fertilizers on crop $\mathrm{N}$ recovery relies on the residual $\mathrm{N}$ that is transformed to slowly available forms (organic $\mathrm{N}$ or $\mathrm{NH}_{4}^{+}$f) during the growing season or that remains in the soil as mineral $\mathrm{N}\left(\mathrm{NH}_{4}{ }^{+}, \mathrm{NO}_{3}{ }^{-}\right)$after harvest (Juma and Paul, 1983). The treatment ENTEC-170 tended to accumulate a greater amount of mineral $\mathrm{N}$ in the soil profile throughout the experiment, being hard to tell how much was coming from the surplus $\mathrm{N}$ remaining after crop harvest or from the slow release of slowly available forms. The accumulation was mainly in the form of nitrate and no differences in soil $\mathrm{NH}_{4}^{+}$content between treatments were found at any sampling time. Probably, 
$\mathrm{NH}_{4}{ }^{+}$accumulated in the soil after fertilizer application as it was reported in similar soils for NI treatments (Diez-Lopez et al., 2008), but as the sampling in our experiment were 6-month apart we could not confirm. A high nitrification rate has being reported for this soil and nitrate leaching losses during the fallow period of fall and winter are relevant in this cropping system, but accumulation of available $\mathrm{N}$ in spring is common (Gabriel and Quemada, 2011). In any case, at sunflower harvest the soil was depleted and no differences in mineral $\mathrm{N}$ were observed between treatments. These results confirm the capacity of sunflower to scavenge the $\mathrm{N}$ and endorse the calculation of $\mathrm{RE}_{\mathrm{N}}$.

The $\mathrm{N}$ retained in the slow available forms is subsequently released to meet crop demand, increasing NUE and reducing losses (Nieder et al., 2011). In many soils, the use of $\mathrm{NI}$ enhances the $\mathrm{N}$ immobilized in the microbial biomass and the $\mathrm{NH}_{4}{ }_{\mathrm{f}} \mathrm{f}$ because of the persistence of $\mathrm{NH}_{4}{ }^{+}$in the soil (Juma and Paul, 1983; Ma et al., 2015). The role of the recently immobilized and fixed ammonium in releasing $\mathrm{N}$ during the subsequent weeks or months is already known (Ma et al. 2015). However, the role of supplying $\mathrm{N}$ during the subsequent years or growing seasons needs to be clarified. Two years after starting the experiment, the potential $\mathrm{N}$ mineralization was higher for soils from the ENTEC than form the ASN or control treatments. These soil samples were taken 11 months after fertilizer application and show that a residual effect due to NI was still present. In the first laboratory studies by Juma and Paul (1983) with Canadian soils, the $\mathrm{N}$ retained in the organic fraction after application of $\mathrm{NH}_{4}{ }^{+}$with a $\mathrm{NI}$ had a half life of 34 weeks, whereas without NI it was $\sim 25$ weeks. Li et al. (1990) indicated the importance of studying the dynamics of $\mathrm{NH}_{4}{ }_{\mathrm{f}}$ fixation and defixation after crop harvest in the Chinese Loess Plateau. The soil in this experiment had a silty clay loam texture and was rich in 2:1 clays, mainly illite (Gabriel et al., 2010). The mean $\mathrm{NH}_{4}{ }^{+}$f content of the samples $\left(120 \mathrm{mg} \mathrm{kg}^{-1}\right.$ ) was in the $60-270 \mathrm{mg} \mathrm{kg}^{-1}$ range reported in the literature for medium-textured soils (Nieder et al., 2011). Therefore, an active process of fixation/defixation probably occurred as reported in other soils of this region by Moyano and Gallardo (1988). Nevertheless, the content of $\mathrm{NH}_{4}{ }_{\mathrm{f}} \mathrm{f}$ was low to detect reliable differences between treatments in any layer, being on the edge of the detection threshold of the analyzer $(0.005 \%)$. The mass spectrometer is extremely sensitive for detecting ${ }^{15} \mathrm{~N}$ enrichment, and the $\delta^{15} \mathrm{~N}$ was higher in the $40-60 \mathrm{~cm}$ layer of soils from the plots treated with ENTEC or ASN-170 than from the control or the ASN-130. This difference may be explained by the increase in $\delta^{15} \mathrm{~N}$ after partial nitrification of the ammonium present in the soil that occurs after application of high rates of synthetic fertilizer or a delay on the nitrifiers activity (Heaton et al., 2012). When the ammonium is only partially nitrified, isotope fractionation can lead to production of nitrate with a $\delta^{15} \mathrm{~N}$ lower than that of the initial ammonium pool. The nitrate is easily loss from the system, whereas the remaining $\mathrm{NH}_{4}^{+}$with higher $\delta^{15} \mathrm{~N}$ is partially fixed in the soil minerals. This effect is more relevant in deeper layers in which the proportion of mineral to organic $\mathrm{N}$ is higher (Nieder et al., 2011). These results are in agreement with other authors that found a higher amount of $\mathrm{NH}_{4}{ }_{\mathrm{f}}$ after NI application (Juma and Paul, 1983; Ma et al. 2015). Therefore, in our experiment the residual effect on ENTEC 
treatments can be explained by an increase in both pools, microbial biomass and $\mathrm{NH}_{4}{ }^{+}$, being the organic more relevant.

It would have been revealing the determination of $\mathrm{NH}_{4}{ }_{\mathrm{f}} \mathrm{f}$ concentration to confirm the isotopic imprint but it was not possible because of the low concentration in samples. There are several methods for determination of $\mathrm{NH}_{4}{ }^{+}$, being the Silva and Bremner (1966) the most broadly used. We used an adaptation of this method proposed by Liang et al. (1999) that uses the same digestion procedure but adds the determination of $\mathrm{N}$ by dry combustion to increase accuracy. The review by Nieder et al. (2011) discussed other methods and the extraction methodology seems to have a large impact on the amount of $\mathrm{NH}_{4}{ }_{\mathrm{f}}$ extracted. Nevertheless, when the differences between treatments $\mathrm{NH}_{4}{ }_{\mathrm{f}}$ are as low as in our case $(<0.003 \% \mathrm{~N})$ it is hard to find a reliable method. The actual methodologies allow to classify soils with different capacity of $\mathrm{NH}_{4}{ }^{+}$fixation, and this might be enough for fertilizer recommendations that give allowance to the residual effect of NI. The release of $\mathrm{N}$ immobilized in the microbial biomass was crucial in short term studies (Juma and Paul, 1983; Ma et al., 2015) as in our long-term experiment. Incubation of soil samples or direct determination of $\mathrm{N}$ in the microbial biomass are good estimates of the potential soil $\mathrm{N}$ supply. Nowadays, the lack of a quick and reliable method to estimate the potential plant-available $\mathrm{N}$ that could be release in the subsequent years after application of fertilizer with a NI is a limitation for practical application. Other field experiments using labeled ${ }^{15} \mathrm{~N}$ fertilizers containing NI might provide further information and help to quantify the contribution of biotic and abiotic pools.

\section{CONCLUSION}

The ammonium sulfate nitrate blended with the DMPP nitrification inhibitor (ENTEC) increased the efficiency of fertilizer $\mathrm{N}$ in a three year crop rotation with respect to conventional ASN. In the following year after application, the recommended rate in the region was reduced $23 \%$ by using ENTEC fertilizers (from 170 to $130 \mathrm{~kg} \mathrm{~N} \mathrm{ha}{ }^{-1}$ ) without decreasing grain yield or quality of maize. In addition, a non-fertilized sunflower planted after the maize was able to scavenge more $\mathrm{N}$ in treatments previously treated with ENTEC than with traditional fertilizers.

After NI fertilizer application, $\mathrm{N}$ was conserved in non-ready soil available forms during at least one year and subsequently released to meet crop demand, thereby mitigating $\mathrm{N}$ losses. The potential $\mathrm{N}$ mineralization obtained from aerobic incubation under controlled conditions was higher for soils from the ENTEC than from the ASN or control treatments, two years after starting the experiment. The higher $\delta^{15} \mathrm{~N}$ in the $40-60$ $\mathrm{cm}$ layer indicated larger non-exchangeable $\mathrm{NH}_{4}{ }^{+}$fixation in soils from the plots treated with ENTEC or ASN-170 than from the control or the ASN-130, even though differences in $\mathrm{NH}_{4}{ }_{\mathrm{f}}^{+}$were not detected due to the low concentration in samples.

In this experiment, sunflower was used to scavenge $\mathrm{N}$ because of its powerful rooting system. However, in other cropping systems these results open the opportunity to increase NUE by designing crop rotations able to profit from the effect of NI on the soil residual N. Multi-year studies of the cumulative effect of fertilizers blended with NI in 
different soils and cropping systems may contribute to the best practice of this fertilizer technology.

\section{ACKNOWLEDGEMENTS}

Spanish Ministry of Economy and Competence (AGL201452310R; IJCI201420175), Comunidad de Madrid (S2013/ABI2717) and EuroChem Agro. The funders had no role in the data collection and analysis or preparation of the manuscript.

\section{REFERENCES}

Abalos, D., Jeffery, S., Sanz-Cobena, A., Guardia, G., and Vallejo, A. (2014). Metaanalysis of the effect of urease and nitrification inhibitors on crop productivity and nitrogen use efficiency. Agriculture Ecosystems \& Environment 189, 136144.

Allen, R. G., Pereira, L. S., Raes, D., and Smith, M. (1998). Crop evapotranspirationGuidelines for computing crop water requirements-FAO Irrigation and drainage paper 56. FAO, Rome 300, D05109.

Alonso-Ayuso, M., Gabriel, J. L., and Quemada, M. (2014). The Kill Date as a Management Tool for Cover Cropping Success. Plos One 9, 12.

Arregui, L. M., and Quemada, M. (2008). Strategies to improve nitrogen use efficiency in winter cereal crops under rainfed conditions. Agronomy Journal 100, 277284.

Barth, G., von Tucher, S., and Schmidhalter, U. (2001). Influence of soil parameters on the effect of 3,4-dimethylpyrazole-phosphate as a nitrification inhibitor. Biology and Fertility of Soils 34, 98-102.

Black, A. S., and Waring, S. A. (1972). Ammonium fixation and availability in some cereal producing in Queensland. Australian Journal of Soil Research 10, 197207.

Bundy, L. G., and Andraski, T. W. (2005). Recovery of fertilizer nitrogen in crop residues and cover crops on an irrigated sandy soil. Soil Science Society of America Journal 69, 640-648.

Diez-Lopez, J. A., Hernaiz-Algarra, P., Arauzo-Sanchez, M., and Carrasco-Martin, I. (2008). Effect of a nitrification inhibitor (DMPP) on nitrate leaching and maize yield during two growing seasons. Spanish Journal of Agricultural Research 6, 294-303.

Ercoli, L., Masoni, A., Pampana, S., Mariotti, M., and Arduini, I. (2013). As durum wheat productivity is affected by nitrogen fertilisation management in Central Italy. European journal of agronomy 44, 38-45.

Gabriel, J. L., Lizaso, J. I., and Quemada, M. (2010). Laboratory versus field calibration of capacitance probes. Soil Science Society of America Journal 74, 593-601.

Gabriel, J. L., and Quemada, M. (2011). Replacing bare fallow with cover crops in a maize cropping system: Yield, N uptake and fertiliser fate. European Journal of Agronomy 34, 133-143. 
Gachon, L. (1972). Kinetics of absorption of chief nutrients in sunflower. Annales Agronomiques 23, 547-566.

Heaton, T. H. E., Stuart, M. E., Sapiano, M., and Sultana, M. M. (2012). An isotope study of the sources of nitrate in Malta's groundwater. Journal of Hydrology 414, 244-254.

Juma, N., and Paul, E. (1983). Effect of a nitrification inhibitor on $\mathrm{N}$ immobilization and release of $15 \mathrm{~N}$ from nonexchangeable ammonium and microbial biomass. Canadian Journal of Soil Science 63, 167-175.

Ladha, J. K., Pathak, H., Krupnik, T. J., Six, J., and van Kessel, C. (2005). Efficiency of fertilizer nitrogen in cereal production: Retrospects and prospects. Advances in Agronomy, 87, 85-156.

Lancashire, P. D., Bleiholder, H., Vandenboom, T., Langeluddeke, P., Stauss, R., Weber, E., and Witzenberger, A. (1991). A uniform decimal code for growthstages of crops and weeds. Annals of Applied Biology 119, 561-601.

Li, C., Fan, X., and Mengel, K. (1990). Turnover of interlayer ammonium in loessderived soil grown with winter-wheat in the Shaanxi province of China. Biology and Fertility of Soils 9, 211-214.

Li, H., Liang, X., Chen, Y., Lian, Y., Tian, G., and Ni, W. (2008). Effect of nitrification inhibitor DMPP on nitrogen leaching, nitrifying organisms, and enzyme activities in a rice-oilseed rape cropping system. Journal of Environmental Sciences-China 20, 149-155.

Liang, B. C., Mackenzie, A. F., and Gregorich, E. G. (1999). Measurement of fixed ammonium and nitrogen isotope ratios using dry combustion. Soil Science Society of America Journal 63, 1667-1669.

Liu, C., Wang, K., and Zheng, X. (2013). Effects of nitrification inhibitors (DCD and DMPP) on nitrous oxide emission, crop yield and nitrogen uptake in a wheatmaize cropping system. Biogeosciences 10, 2427-2437.

Ma, Q., Wu, Z., Shen, S., Zhou, H., Jiang, C., Xu, Y., Liu, R., and Yu, W. (2015). Responses of biotic and abiotic effects on conservation and supply of fertilizer $\mathrm{N}$ to inhibitors and glucose inputs. Soil Biology \& Biochemistry 89, 72-81.

Martinez, F., Palencia, P., Weiland, C. M., Alonso, D., and Oliveira, J. A. (2015). Influence of nitrification inhibitor DMPP on yield, fruit quality and SPAD values of strawberry plants. Scientia Horticulturae 185, 233-239.

Menendez, S., Merino, R., Pinto, M., Gonzalez-Murua, C., and Estavillo, J. M. (2009). Effect of N-(n-butyl) Thiophosphoric Triamide and 3,4 Dimethylpyrazole Phosphate on Gaseous Emissions from Grasslands under Different Soil Water Contents. Journal of Environmental Quality 38, 27-35.

Moyano, A., and Gallardo, J. (1988). Fixed ammonium determination in some clay soils. Communications in Soil Science \& Plant Analysis 19, 225-238.

Nieder, R., Benbi, D. K., and Scherer, H. W. (2011). Fixation and defixation of ammonium in soils: a review. Biology and Fertility of Soils 47, 1-14.

Pasda, G., Hahndel, R., and Zerulla, W. (2001). Effect of fertilizers with the new nitrification inhibitor DMPP (3,4-dimethylpyrazole phosphate) on yield and 
quality of agricultural and horticultural crops. Biology and Fertility of Soils 34, 85-97.

Quemada, M., Baranski, M., Nobel-de Lange, M. N. J., Vallejo, A., and Cooper, J. M. (2013). Meta-analysis of strategies to control nitrate leaching in irrigated agricultural systems and their effects on crop yield. Agriculture Ecosystems \& Environment 174, 1-10.

Quemada, M., Gabriel, J.L., and Zarco-Tejada, P. (2014). Airborne hyperspectral images and ground-level optical sensors as assessment tools for maize nitrogen fertilization. Remote Sensing 6, 2940-2962.

Ruser, R., and Schulz, R. (2015). The effect of nitrification inhibitors on the nitrous oxide (N2O) release from agricultural soils - a review. Journal of Plant Nutrition and Soil Science 178, 171-188.

Sharma, S. N., and Prasad, R. (1996). Use of nitrification inhibitors (neem and DCD) to increase N efficiency in maize-wheat cropping system. Fertilizer Research 44, 169-175.

Silva, J. A., and Bremner, J. M. (1966). Determination and isotope-ratio analysis of different forms of nitrogen in soils. 5. Fixed ammonium. Soil Science Society of America Proceedings 30, 587-594.

Stanford, G., and Smith, S. J. (1972). Nitrogen mineralization potentials of soils. Soil Science Society of America Proceedings 36, 465-472.

Trenkel, M. E. (2010). Slow- and controlled- release and stabilized fertilizers: an option for enhancing nutrient efficiency in agriculture. IFA., Paris (France).

Weiske, A., Benckiser, G., Herbert, T., and Ottow, J. C. G. (2001). Influence of the nitrification inhibitor 3,4-dimethylpyrazole phosphate (DMPP) in comparison to dicyandiamide (DCD) on nitrous oxide emissions, carbon dioxide fluxes and methane oxidation during 3 years of repeated application in field experiments. Biology and Fertility of Soils 34, 109-117.

Wissemeier, A., Linzmeier, W., Gutser, R., Weigelt, W., and Schmidhalter, U. (2001). The new nitrification inhibitor DMPP (ENTEC $®)$ - Comparisons with DCD in model studies and field applications. In "Plant Nutrition", pp. 702-703. Springer.

Wu, S., Wu, L., Shi, Q., Wang, Z., Chen, X., and Li, Y. (2007). Effects of a new nitrification inhibitor 3,4-dimethylpyrazole phosphate (DMPP) on nitrate and potassium leaching in two soils. Journal of Environmental Sciences-China 19, 841-847.

Zerulla, W., Barth, T., Dressel, J., Erhardt, K., von Locquenghien, K. H., Pasda, G., Radle, M., and Wissemeier, A. H. (2001). 3,4-Dimethylpyrazole phosphate (DMPP) - a new nitrification inhibitor for agriculture and horticulture - An introduction. Biology and Fertility of Soils 34, 79-84. 